$\langle$ Concise communication〉

\title{
Hydrogen Peroxide Vapour in the Proximity of Hydrogen Peroxide Sterilisers
}

\author{
Rika YoshIDA ${ }^{1,2)}$ and Hiroyoshi KobAYASHI ${ }^{1)}$ \\ 1) Tokyo Healthcare University Postgraduate School \\ ${ }^{2)}$ Kinki University Hospital, Infection Control Section, Safty Management Department
}

\begin{abstract}
Summary
Background: Some employees engaged in central services in a hospital have experienced irritation to the eyes and throat near the hydrogen peroxide (HP) steriliser.

Method: The concentrations of hydrogen peroxide vapour (HPV) in the proximity of HP sterilisers (low-temperature hydrogen peroxide gas plasma steriliser: Sterrad NX ${ }^{\circledR}$, Sterrad $100 \mathrm{~S}^{\circledR}$, and Sterrad $200^{\circledR}$, Johnson \& Johnson, and Low-temperature vaporized hydrogen peroxide steriliser: Amsco VPRO1 ${ }^{\circledR}$, Sakura Seiki) were measured with an electrochemical detector.

Results: HPV was present at higher concentrations than anticipated.

Conclusion: Adequate air conditioning, donning gloves for bag handling, supplied-air respirator use for door opening, and other measures for the security of healthcare personnel should be seriously reevaluated.
\end{abstract}

Key words: Hydrogen Peroxide, Vapour, Circumstance, Steriliser

(Jpn J Environment Infect 2011; 26: 239-42)

\section{Introduction:}

Some employees of the central services in a hospital have reported irritation to the eyes and throat near a hydrogen peroxide (HP) steriliser. In this preliminary study, the hydrogen peroxide vapour (HPV) concentrations in close proximity to a HP steriliser were tested with an electrochemical detector (PacIII ${ }^{\circledR}$, Dräger, sensitivity: 0-20 parts per million (ppm) air) were found to be rather high.

\section{Method:}

The sterilisers in a tertiary university hospital (941 beds) and two community educational hospitals ( 605 beds and 310 beds) were tested. Additionally, another steriliser installed in a university laboratory for research was tested. The concentrations of HPV in the proximity of the HP sterilisers (low-temperature hydrogen peroxide gas plasma steriliser: Ster$\operatorname{rad} \mathrm{NX}^{\circledR}$, Sterrad $100 \mathrm{~S}^{\circledR}$, and Sterrad $200^{\circledR}$, Johnson \& Johnson, and Low-temperature vaporized hydrogen peroxide steriliser: Amsco V-PRO1 ${ }^{\circledR}$, Sakura Seiki) were examined every 10 seconds with an electrochemical detector (Polytron $7000^{\circledR}$, Dräger, sensitivity: $0-300 \mathrm{ppm}$, uncertainty: $\leqq \pm 25 \%$ ). The drainage port of the exhaust air from the space sur- rounding the inner chamber, inside the sterilising chamber, sterilising bags after sterilisation, and the environmental air were tested.

\section{Results:}

The concentrations of HPV in the proximity of each steriliser are shown in Figures 1a-d and 2. Higher HPV concentrations of above $100 \mathrm{ppm}$ were detected in the exhaust filtered through the catalytic convertor for the air between the inner sterilising chamber and outer surrounding panels of one of the sterilisers, as shown in Figures 1-b and 1-c. This catalytic convertor was still in the recommended use period and not recommended for replacement. After changing the unit to a new one, the exhaust air showed a lower concentration of below $1 \mathrm{ppm}$, but the concentration in the sterilising chamber after opening at the end of this process was $49 \mathrm{ppm}$.

Much higher HPV than the recommended concentration of $1 \mathrm{ppm}$ was detected on the surfaces and the insides of the sterilising bags, as shown in Figures 1-a, 1-b, 1-d, and 2. The concentrations at mouth height over the sterilising bags on the cart were 0.2 to 4 ppm as shown in Figures 1-a and 2 . 


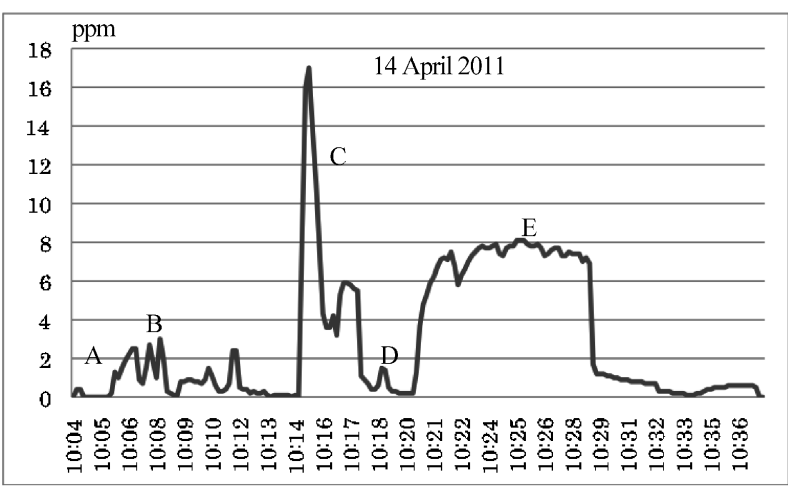

$\mathrm{a}$

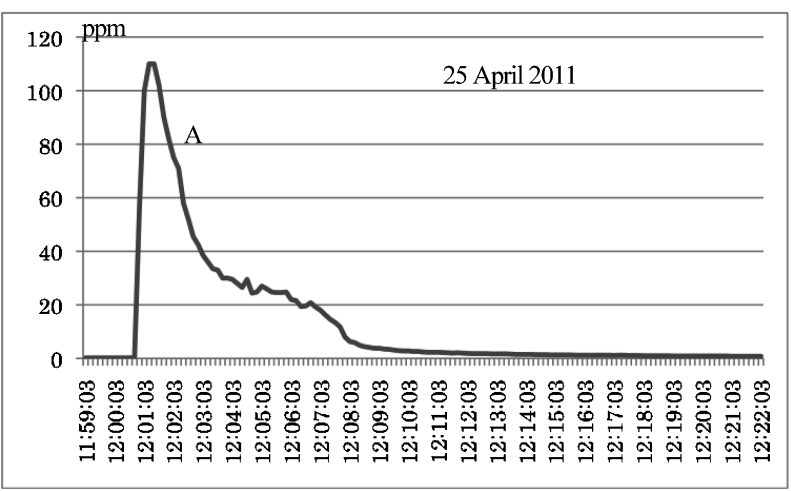

$\mathrm{c}$

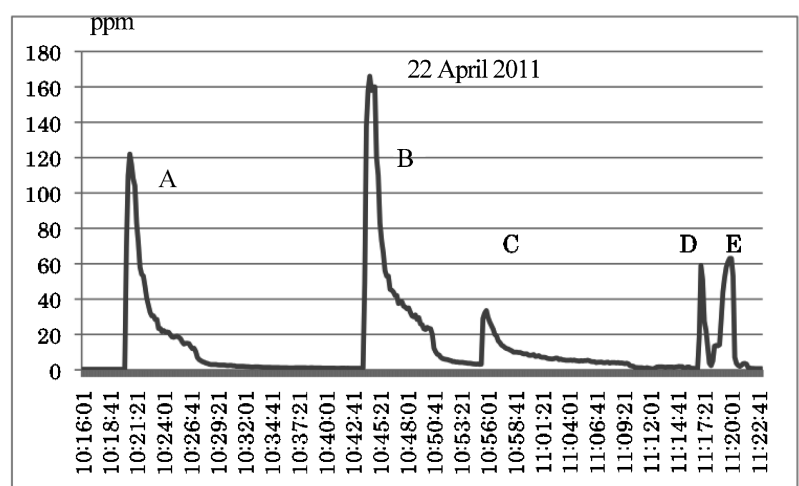

$\mathrm{b}$

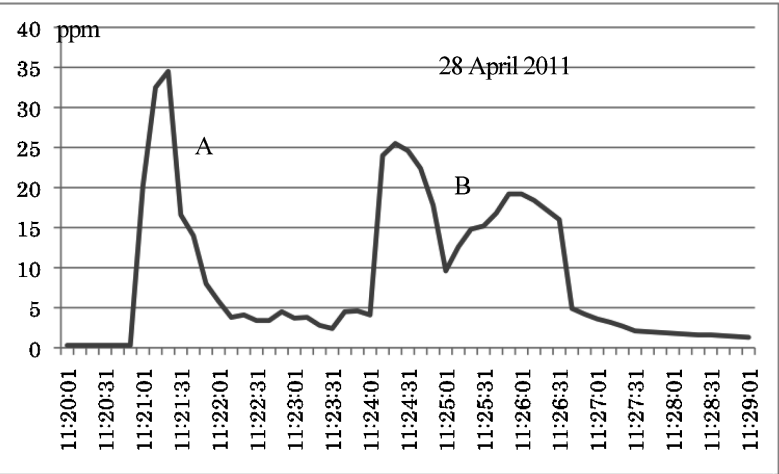

d

Fig. 1-a Concentration of hydrogen peroxide vapour near the Sterrad NX ${ }^{\circledR}(A-D)$ and Sterad $200^{\circledR}(E)$

Detected every 10 seconds with an electrochemical detector (Polytron $7000^{\circledast}$, Dräger) No HPV $(0 \mathrm{ppm})$ was detected in the the air around the exhaust port on the top panel. The air between the inner sterilising chamber and outer panel chamber is exhausted after passing through the catalytic convertor.

A: Inside the sterilising chamber $(0 \mathrm{ppm})$

B: In front of steriliser door just after opening

C: Inside the outer bag after opening

D: At the height of mouth over the bags on the cart

E: On the surface of outer bag removed from another sterilising chamber $14 \mathrm{hr} 11 \mathrm{~min}$ after sterilisation

Fig. 1-b Concentration of hydrogen peroxide vapour near the Sterrad $200^{\circledR}$

A, B and C: At the exhaust port on the top panel just after hydrogen peroxide infusion into the sterilising chamber. The detected air passed through this catalytic convertor before the recommended limit for exchange.

C: Inside the sterilising chamber just after the sterilising process.

D: Surface of non-woven fabric side of the sterilising bag.

Fig. 1-c Concentration of hydrogen peroxide vapour near the Sterrad $200^{\circledR}$

A: Again at the exhaust port on the top panel of the same steriliser as Figure 2.

Fig. 1-d Concentration of hydrogen peroxide vapour near the Sterrad $100 \mathrm{~S}^{\mathbb{B}}$

A: Inside the sterilising chamber just after the sterilisation process.

B: Surface of non-woven fabric side of the sterilising bag

\section{Discussion:}

The permissible exposure limit (PEL) of the Occupational Safety and Health Administration (OSHA) for hydrogen peroxide is $1 \mathrm{ppm}(1.4 \mathrm{mg} /$ $\mathrm{m}^{3}$ ) as an 8 -hour time-weighted average (TWA) concentration, and the National Institute for Occupational Safety and Health (NIOSH) has established a recommended exposure limit (REL) for hydrogen peroxide of $1 \mathrm{ppm}\left(1.4 \mathrm{mg} / \mathrm{m}^{3}\right)$ as a TWA for up to a 10-hour workday and a 40-hour workweek ${ }^{1)}$.

In the present study, higher concentrations of HPV above $1 \mathrm{ppm}$ were detected on the surfaces and insides of the sterilising bags. The results showed that the concentrations on the surfaces and insides of the four different sterilizing bags were high and were the same overall. However, this study did not examine the effective aeration time to diminish the residual HP, since this was beyond the scope of this study. 


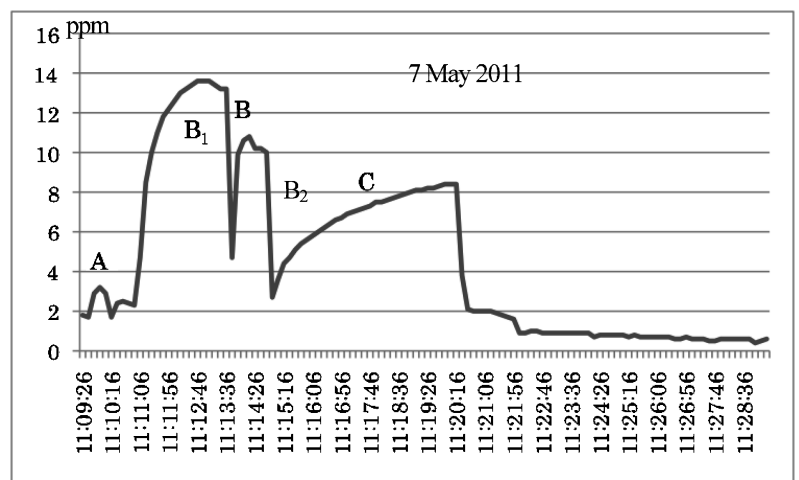

Fig. 2 Concentration of hydrogen peroxide vapour near the Amsco V-PRO1 ${ }^{\circledR}$

No HPV was detected in the exhausted air passed through catalytic convertor which is installed below the sterilising chamber.

A: At the height of the mouth in front of the steriliser door just after opening.

B: Surface of the sterilising bag $\left(B_{1}\right.$ : Non-woven,

$\mathrm{B}_{2}$ : film sites).

$\mathrm{C}$ : Inside the sterilising bag just after opening.

Higher concentrations of HPV above those immediately dangerous to life or health (IDLH, 75 ppm) were detected in the exhaust air from one steriliser, but after replacing the convertor, the HPV concentration decreased to lower than the recommended TWA. The problem is that the malfunctioned catalytic convertor was still in the use period recommended by the supplier. The safety and availability of the convertor should be reevaluated. Additionally, the provision for the exhaust air from the surrounding space of the inner sterilising chamber should be reconsidered. Many healthcare workers engaged in sterilisation have considered the steriliser to be safe, but the present results have shown dangerously high concentrations of HPV in the near proximity.
The colorimetric method is the only official test method recommended by OSHA ${ }^{3)}$. The range for this colorimetric method is useful only from $2 \mu \mathrm{g}$ $\mathrm{H}_{2} \mathrm{O}_{2}$ up to about $100 \mu \mathrm{g} \mathrm{H}_{2} \mathrm{O}_{2}$ which corresponds to 0.06 to $3.0 \mathrm{mg} \mathrm{H}_{2} \mathrm{O}_{2} / \mathrm{m}^{3}$ for a 100 liter air sample. The electrochemical detector with sensitivity of 0 to $300 \mathrm{ppm}$ was employed in this study, and higher concentrations of HPV in the steriliser environment could be detected.

The HP steriliser is the most useful and safest method for the sterilisation of heat labile medical devices. It is very important to obtain good quality of sterility assurance. However, the security of healthcare personnel engaged in the sterilising setting has to be reconsidered, although HP is much safer than ethylene oxide or formaldehyde.

In conclusion, adequate air conditioning, donning gloves for bag handling, use of the supplied-air respirator when the door is opened, and other measures for the security of healthcare personnel should be seriously reevaluated.

\section{References}

1) CDC. NIOSH. NIOSH pocket guide to chemical hazards. DHHS (NIOSH) Publication No. 2005149.

2) Cohen IR, Purcell TC. Spectrophotometric determination of hydrogen peroxide with 8-quinolinol. Analytical Chrmistry 1967; 39: 131-132.

3) OSHA. Occupational health guideline for hydrogen peroxide.

http://www.osha.gov/dts/sltc/methods/inorganic /id006/hydrogen_peroxide.html (on 8 May 2011 accessed)

\section{Reprint Request:}

Hiroyoshi Kobayashi (Corresponding Author); Tokyo Healthcare University Postgraduate School 4-1-7 Higashi-Gotanda, Shinagawa-ku, Tokyo, Japan 1418648

E-mail;hk@thcu.ne.jp 


\title{
過酸化水素滅菌器における過酸化水素蒸気が環境に及ぼす影響
}

\author{
吉田 理香 1,2$) \cdot$ 小林 寛伊 1 - \\ 1) 東京医療保健大学大学院 \\ 2)近畿大学医学部附属病院 安全管理部 感染対策室
}

\section{抄 録}

背 景

病院の滅菌供給業務に携わっている医療従事者の何人かは, 過酸化水素滅菌器周辺で眼や 咽頭部に刺激を体験している。

方 法

過酸化水素滅菌器(過酸化水素低温ガスプラズマ滅菌器 : ステラッド $\mathrm{NX}^{\circledR}$, ステラッド $100 \mathrm{~S}^{\circledR}$, ステラッド $200^{\circledR}$, ショョンソン \& ションソンと過酸化水素ガス低温滅菌器 : アムスコ V-PRO1 ${ }^{\circledR}$ サクラ精機)に打ける環境の過酸化水素濃度について電気化学検出器を用いて調べ た。

結 果

環境における過酸化水素濃度は予測される濃度より高い值を示した. 結 論

過酸化水素滅菌器を使用する時の医療従事者の安全を守るために, 滅菌器周辺の換気, 滅 菌物に触れる時の手袋着用, 滅菌器のドアを開けるときのマスク着用などを再評価する必要 がある。

キーワード : 過酸化水素, 蒸気, 環境, 滅菌器

〔連絡先 : ₹141-8648 東京都品川区東五反田4-1-17 東京医療保健大学大学院 学長 小林寬伊 E-mail;hk@thcu.ne.jp] 